\title{
Jus Lemon untuk menurunkan Hipertensi pada Warga di Desa Menganti Kabupaten Cilacap
}

\author{
Susilawati $^{1^{*}}$, Kasron ${ }^{2}$ \\ ${ }^{1}$ Program Studi D-III Kebidanan, STIKes Al-Irsyad Al-Islamiyyah, Cilacap \\ ${ }^{2}$ Program Studi S-1 Keperawatan STIKes Al-Irsyad Al-Islamiyyah, Cilacap \\ *susilawatimdf@gmail.com
}

Received 21 August 2019; Accepted 28 August 2019; Published 5 September 2019

\begin{abstract}
ABSTRAK
Hipertensi merupakan faktor risiko penyakit kardiovaskuler yang menyebabkan kematian. Hipertensi merupakan penyakit dengan peringkat pertama yang paling sering dijumpai di setiap negara akibat perubahan gaya hidup yang tidak sehat. Pengobatan penyakit hipertensi dapat menggunakan pengobatan modern, namun dapat juga menggunakan pengobatan alternatif. Pengendalian hipertensi sangat penting dilakukan untuk mencegah komplikasi. Pengabdian kepada masyarakat ini dilakukan di Desa Menganti, dimana didapatkan data bahwa mayoritas warga belum mengetahui informasi tentang hipertensi, penyebab, komplikasi, pencegahan dan penatalaksanaannya. Tujuan dari pengabdian masyarakat ini adalah meningkatkan pengetahuan dan keterampilan kader dan warga tentang hipertensi, penyebab, komplikasi, pencegahan dan penatalaksanaannya. Meningkatkan kemampuan kader dan warga tentang upaya penurunan tekanan darah dengan mengkonsumsi jus lemon. Metode kegiatan dilakukan secara bertahap dengan kegiatan sebagai berikut: Meningkatkan pengetahuan kader, meningkatkan pengetahuan dan keterampilan warga, simulasi praktek, dan evaluasi. Hasil pengabdian menunjukan terjadi peningkatan pengetahuan kader-warga tentang upaya pencegahan dan penurunan hipertensi dan terdapat penurunan tekanan darah pada warga yang menderita hipertensi setelah mengkonsumsi jus lemon.
\end{abstract}

Kata kunci : Jus lemon, hipertensi, tekanan darah

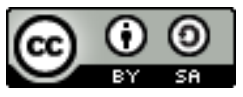

This is an open-acces article distributed under the terms of the Creative Commons Attribution-ShareAlike 4.0 International License.

\section{PENDAHULUAN}

Seiring dengan pertambahan usia terjadi perubahan pada sistem organ tubuh diantaranya jantung dan pembuluh darah. Hipertensi merupakan kelainan sirkulasi darah yang sering terjadi. Hipertensi hanyalah gejala yang ditandai oleh kenaikan tekanan darah nadi melewati batas normal yaitu di atas 140/90 $\mathrm{mmHg}$ atau lebih (Kurniawan, 2002).

Hipertensi (tekanan darah tinggi) merupakan faktor risiko utama kardiovaskuler yang merupakan penyebab utama kematian di seluruh dunia. Hipertensi sering dijumpai sejalan dengan perubahan gaya hidup seperti merokok, obesitas, kurang aktivitas fisik, dan stres psikososial (He et al., 2001).

Data WHO tahun 2014 menunjukkan di dunia terdapat sekitar 972 juta orang atau 26,4\% mengidap hipertensi dengan perbandingan $26,6 \%$ pria dan 26,1\% wanita (World Health Organization, 2014). Data Riskesdas 2013 menunjukkan data hipertensi di Indonesia berkisar 30\% dari total jumlah penduduk dengan kejadian komplikasi penyakit kardiovaskular lebih banyak pada perempuan 52\% dibandingkan laki-laki 48\%. Data SKRT 2013, hipertensi di Pulau Jawa 41,9\% dari jumlah penduduk 
124 juta dengan rentang kejadian di masing-masing provinsi 36,6\%-47,7\% (Dinas Kesehatan Republik Indonesia, 2013).

Hipertensi merupakan penyakit degeneratif, sehingga penderitanya akan terus bertambah dengan semakin bertambahnya usia. Lansia Indonesia dengan usia lebih dari 60 tahun sebesar 65,4\% dari jumlah penduduk 232,9 juta mengalami hipertensi dan selain itu hipertensi terjadi pada lebih dari $2 / 3$ individu dengan usia lebih dari 65 tahun. Pada lansia terjadi penebalan katup jantung dan berkurangnya elastisitas pembuluh darah sehingga terjadi perubahan resistensi pembuluh darah perifer akibatnya terjadi peningkatan tekanan darah.

Hipertensi merupakan penyakit kronis serius yang bisa merusak organ tubuh. Hipertensi setiap tahun menjadi penyebab 1 dari setiap 7 kematian (7 juta per tahun) yang menimbulkan komplikasi diantaranya gangguan pembuluh darah otak (1.9\%), stroke $15,4 \%$, penyakit jantung koroner $(1.5 \%)$ dan gagal ginjal (1.4\%), penyakit jantung iskemik 5,1\% (Fantidis et al., 2014). Dengan melihat komplikasi dari penyakit hipertensi di atas maka dibutuhkan upaya pencegahan dan upaya penurunan pada orang-orang yang beresiko dan menderita hipertensi.

Pengobatan penyakit hipertensi seiring perkembangan dunia kesehatan yang semakin pesat tidak hanya menggunakan pengobatan modern, namun dapat menggunakan pengobatan alternatif. Pengendalian hipertensi sangat penting dilakukan untuk mencegah komplikasi. Obat-obatan dapat mengatasi masalah hipertensi tetapi tidak dapat menyembuhkannya. Obat hanya dapat mengembalikan tekanan darah kembali normal tetapi tidak dapat mengendalikannya. Obat juga mempunyai efek samping yang berbahaya. Oleh karena itu pengendalian memerlukan penatalaksanaan keperawatan terutama pengaturan gaya hidup, seperti : pengontrolan diet, olahraga, dan aktifitas yang sebaiknya dilaksanankan secara cermat dan berkesinambungan.

Penyebab utama terjadinya hipertensi adalah faktor asteroklerosis yang didasari dengan konsumsi lemak berlebih. Pengurangan konsumsi lemak sebaiknya dimulai sejak dini sebelum terjadi hipertensi, terutama pada orang-orang yang dengn riwayat keturunan hipertensi dan menjelang usia lanjut. Sebaiknya umur 40 tahun pada wanita atau menjelang menopause agar berhati-hati dalam mengkonsumsi lemak. Prinsip utama dengan pola makan sehat/ "gizi seimbang", yaitu mengkonsumsi makanan yang seimbang dari "kuantitas" dan "kualitas".

Pengendalian hipertensi sangat penting dilakukan untuk mencegah komplikasi. Obat-obatan dapat mengatasi masalah hipertensi tetapi tidak dapat menyembuhkannya. Obat hanya dapat mengembalikan tekanan darah kembali normal tetapi tidak dapat mengendalikannya. Obat juga mempunyai efek samping yang berbahaya. Oleh karena itu pengendalian memerlukan penatalaksanaan keperawatan terutama pengaturan gaya hidup, seperti: pengontrolan diet, olahraga, dan aktifitas yang sebaiknya dilaksanankan secara cermat dan berkesinambungan (Martin \& Advisor, 2009). Dalam dunia medis dikenal dan diakui adanya pengobatan komplementer untuk hipertensi salah satunya ialah pemanfaatan tanaman lokal. Hasil penelitian (Sari et al., 2012) tentang manfaat penggunaan jus lemon terhadap tekanan darah bahwa terdapat perbedaan yang signifikan secara statistik kelompok intervensi dan kelompok kontrol dalam nilai rata-rata tekanan darah. Demikian juga penelitian (Adibelli, Dilek, \& Akpolat, 2009) menunjukan bahwa penggunaan jus lemon dapat digunakan sebagai alternative untuk menurunkan tekanan darah pada penderita hipertensi. Penggunaan jus lemon dapat menurunkan tekanan darah setelah dikonsumsi selama antara 7 sampai 14 hari.

Data hasil pengabdian tim pada tahun 2018 menunjukan bahwa mayoritas warga menderita hipertensi. Pengabdian kepada masyarakat ini dilakukan di Desa Menganti, dimana didapatkan data sebelumnya bahwa warga belum mengetahui manfaat tanaman atau alternative makanan untuk menurunkan tekanan darah pada penderita hipertensi.

\section{BAHAN DAN METODE}

Pengabdian kepada masyarakat ini dilaksanakan di Desa Menganti. Sasaran pelaksanaan kegiatan adalah seluruh kader dan seluruh warga di Desa Menganti. Sasaran pelaksanaan adalah seluruh warga yang memiliki riwayat hipertensi atau memiliki resiko terjadinya hipertensi maupun warga dengan tekanan darah normal. 
Adapun metode pelaksanaannya adalah:

1. Pre test

Pada tahap ini dilakukan penilaian pengetahuan kader dan warga menggunakan kuesioner sederhana menggunakan 15 pertanyaan dengan jawaban benar dan salah. Kuesioner berisi tentang konsep hipertensi, penyebab, komplikasi, pencegahan dan penatalaksanaannya.

2. Materi dan Demonstrasi

Pada tahap ini diberikan materi tentang hipertensi, penyebab, komplikasi, pencegahan dan penatalaksanaannya. Selanjutnya dilakukan demonstrasi salah satu terapi alternative pembuatan jus lemon.

3. Post test

Pada tahap ini dilakukan penilaian kembali menggunakan kuesiner yang sama saat pretest. Selanjutnya dilakukan evaluasi dengan demostrasi kembali oleh peserta untuk mengevaluasi pembuatan jus lemon pada kader dan warga.

4. Intervensi tindakan pemberian jus lemon

Pada hari pertama mengajarkan cara membuat jus lemon, dengan sebelumnya dilakukan pengukuran tekanan darah. Pada warga yang mengalami hipertensi diberikan intervensi pemberian jus lemon selama 7 hari.

5. Monitoring dan evaluasi

Pada tahap ini tim pengabdian bekerjasama dengan kader melakukan monitoring dan evaluasi dalam satu minggu. Monitoring terakhir dilakukan pada hari kedelapan dengan mengukur tekanan darah pada warga yang diberikan intervensi jus lemon.

HASIL

Berikut kategori hasil pengukuran tekanan darah pada warga berdasarkan kategori dewasa (20-59 tahun) dan lansia ( $>60$ tahun).

Tabel 1. Nilai Pengukuran Tekanan Darah Warga dan Kader Sebelum Kegiatan PKM

\begin{tabular}{lcc}
\hline Kategori & Jumlah & Persentase \\
\hline Usia Dewasa $\mathrm{n}=18$ & & \\
Normal $(<130)$ & 12 & 66.67 \\
Pre-Hipertensi $(130-140)$ & 3 & 16,67 \\
Hipertensi $(>140)$ & 3 & 16,67 \\
Usia Lansia n=6 & & \\
Normal $(<140)$ & 3 & 50,00 \\
Pre-Hipertensi $(150-160)$ & 2 & 33,33 \\
Hipertensi $(>160)$ & 1 & 16,67 \\
\hline
\end{tabular}

Tabel 2. Nilai Pengukuran Nadi Sebelum Kegiatan PKM

\begin{tabular}{lccc}
\hline Peserta & Jumlah & Rerata-Simpangan Baku & Median (Min-Max) \\
\hline Usia Dewasa & 18 & $90,0 \pm 9,1$ & $88(80-110)$ \\
\hline Usia Lansia & 6 & $94,4 \pm 8,4$ & $90(80-100)$ \\
\hline
\end{tabular}


Tabel 3. Nilai Pre Test Pengetahuan Kader Sebelum Pemberian Materi

\begin{tabular}{lccc}
\hline Peserta & Jumlah & Rerata-Simpangan Baku & Median (Min-Max) \\
\hline Usia Dewasa & 18 & $9,4 \pm 1,1$ & $9(8-11)$ \\
\hline Usia Lansia & 6 & $9,6 \pm 1,6$ & $9(8-13)$ \\
\hline
\end{tabular}

Tabel 4. Nilai Post Test Pengetahuan Kader-Warga Setelah Pemberian Materi

\begin{tabular}{lccc}
\hline Peserta & Jumlah & Rerata-Simpangan Baku & Median (Min-Max) \\
\hline Usia Dewasa & 18 & 15 & 15 \\
\hline Usia Lansia & 6 & $14,8 \pm 0,4$ & $15(14-15)$ \\
\hline
\end{tabular}

Table 5. Nilai Pengukuran Tekanan Darah dan Nadi Warga Yang Menderita Hipertensi Sebelum dan Setelah Kegiatan PKM

\begin{tabular}{lcccc}
\hline Responden & TD1 & TD2 & N1 & N2 \\
\hline Usia Dewasa (3) & & & & \\
Responden 1 & $150 / 80$ & $145 / 80$ & 94 & 94 \\
Responden 2 & $145 / 90$ & $145 / 90$ & 94 & 98 \\
Responden 3 & $160 / 85$ & $150 / 80$ & 90 & 98 \\
Usia Lansia (1) & & & & \\
Responden 1 & $170 / 90$ & $170 / 90$ & 98 & 98 \\
\hline
\end{tabular}

Ket: TD1: Tekanan Darah sebelum PKM, TD2: Tekanan Darah setelah PKM, N1: Nadi sebelum PKM, N2: Nadi setelah PKM

\section{PEMBAHASAN}

Pelatihan pada kader dan warga dilakukan bertempat di Rumah Warga di Desa Menganti. Pada kegiatan ini dihadiri oleh 5 kader, 19 warga dan TIM Pengabdian. Seluruh peserta kegiatan dilakukan pengukuran tekanan darah, nadi dan dilakukan pengukuran pengetahuan. Selanjutnya seluruh peserta diberikan materi tentang hipertensi dan dilakukan demostrasi pembuatan jus lemon. Peserta sangat antusias mengikuti kegiatan dan pemaparan materi hipertensi yang diberikan tim pengabdian masyarakat STIKES Al-Irsyad Al-Islamiyyah, serta dengan adanya demonstrasi pembuatan jus lemon, peserta dapat mempraktekkan pembuatan jus lemon dengan benar dan dengan takaran yang tepat. Masyarakat yang mengalami hipertensi dianjurkan mengkonsumsi jus lemon selama 7 hari dan selanjutnya dilakukan pengukuran tekanan darah dan nadi kembali. Evaluasi menunjukkan pengetahuan kader-warga meningkat setelah diberikan pemaparan materi dan kaderwarga yang mengalami hipertensi mengalami penurunan tekanan darah, sehingga diharapkan dapat menghindari komplikasi yang timbul. Kader-warga berharap kegiatan seperti ini bisa dilakukan kembali dikesempatan yang lain.

\section{KESIMPULAN}

Pengendalian hipertensi sangat penting dilakukan untuk mencegah komplikasi. Obat-obatan dapat mengatasi masalah hipertensi tetapi tidak dapat menyembuhkannya. Obat hanya dapat mengembalikan tekanan darah kembali normal tetapi tidak dapat mengendalikannya. Obat juga mempunyai efek samping yang berbahaya. Oleh karena itu pengendalian memerlukan penatalaksanaan keperawatan terutama pengaturan gaya hidup, seperti: pengontrolan diet, olahraga, dan aktifitas yang sebaiknya dilaksanankan secara cermat dan berkesinambungan. Dalam dunia medis dikenal dan diakui adanya pengobatan komplementer untuk hipertensi salah satunya ialah pemanfaatan tanaman lokal. Pemanfaatan jus lemon untuk menurunkan hipertensi sudah Hasil penelitian tentang manfaat penggunaan jus lemon terhadap tekanan darah bahwa terdapat perbedaan yang signifikan secara statistik kelompok intervensi dan kelompok kontrol dalam nilai rata-rata 
tekanan darah. Demikian juga penelitian menunjukan bahwa penggunaan jus lemon dapat digunakan sebagai alternative untuk menurunkan tekanan darah pada penderita hipertensi. Penggunaan jus lemon dapat menurunkan tekanan darah setelah dikonsumsi selama antara 7 sampai 14 hari.

\section{REFERENSI}

Adibelli, Z., Dilek, M., \& Akpolat, T. (2009). Lemon juice as an alternative therapy in hypertension in Turkey. International Journal of Cardiology, 135(2), e58-e59. https://doi.org/10.1016/j.ijcard.2008.03.085.

Dinas Kesehatan Republik Indonesia. (2013). Riset Kesehatan Dasar 2013. Riset Kesahatan Dasar, 111-116. https://doi.org/1 Desember 2013.

Fantidis, P., Sanchez, E., Tarhini, I., Khan, I., Pineda, T., Corrales, J., a., \& Gonzalez, J., R. (2014). Left Ventricular Assist Devices in Patients With End-Stage Heart Failure: Suggestion of an Alternative Treatment Based on Clinically Well-Known Concepts. Angiology, 65(10), 861-868. https://doi.org/10.1177/0003319713518838.

Guyatt, G. (2000). The Six Minute Walking. Canadian Journal of Cardiology, 534, 356-362.

Guyatt, G., Sullivan, M., J., Thompson, P., J., Pugsley, S., Taylor, D., W., \& Berman, L., B. (1985). The 6-minute walk: a new measure of exercise capacity in patients with chronic heart failure. Canadian Medical Association Journal, 132(April 15), 919-923.

He, J., Ogden, L., G., Bazzano, L., A., Vupputuri, S., Loria, C., \& Whelton, P., K. (2001). Risk Factors for Congestive Heart Failure in US Men and Women. Archives of Internal Medicine, 161, 996-1002.

Kato, Y., Domoto, T., Hiramitsu, M., Katagiri, T., Sato, K., Miyake, Y., \& Harada, T. (2014). Effect on blood pressure of daily lemon ingestion and walking. Journal of Nutrition and Metabolism, 2014(September 2011). https://doi.org/10.1155/2014/912684.

Kurniawan, A. (2002). Gizi seimbang untuk mencegah hipertensi. Seminar, (September), 1-18.

Martin, C., W., \& Advisor, S., M. (2009). Alternative medicine: Some definitions, evidence \& references. Alternative Medicine, (October). Retrieved from www.worksafebc.com/health_care.../PDF/alternative_medicine.pdf.

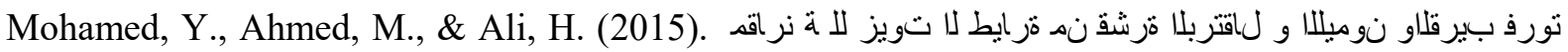
ï. Sudan University of Science and Technology, 1(1), 1-37.

Sari, A., Selim, N., Dilek, M., Aydogdu, T., Adibelli, Z., Büyükkaya, P., \& Akpolat, T. (2012). Effect of lemon juice on blood pressure. Journal of Experimental and Clinical Medicine, 29, 38-41. https://doi.org/10.5835/jecm.omu.29.01.010.

World Health Organization. (2014). Health Situation. WHO Country Cooperation Strategy, (April), $0-1$. Retrieved from http://www.who.int/countryfocus/cooperation_strategy/ccsbrief_uga_en.pdf. 